[Harré Hindmarsh, J., Bell, A., Addison, A., Gunn, C., \& McGray, D. (1994). Community and Continuing Education in 1993: Who is Deciding? Who is Benefiting? New Zealand Annual Review of Education, 3, 285-318]

\section{Community and Continuing Education in 1993: Who is Deciding? Who is Benefiting?}

\author{
JENNIE HARRE HINDMARSH WITH ATAWHAI BELL, ALAN \\ ADDISON, COLIN GUNN AND DOROTHY MCGRAY
}

\section{Abstract:}

1993 was the International Year of Indigenous Peoples, the centenary of Women's Suffrage in Aotearoa/New Zealand, and an election year. In recognition of these events, this review of trends and issues in policies, practices and research in community and continuing education places some emphasis on noting how these relate to Maori and women as learners and providers. The first section examines trends and issues evident in policy developments - from the field, the government and the three other main political parties; and the second section, trends and issues in the provision of learning opportunities through local and national community organisations, school community education, institutions and private providers. Provision and policy development based in Iwi and Maori worlds are not covered.

1

993 was the United Nations International Year of Indigenous Peoples and, in Aotearoa New Zealand, the centenary of Women's Suffrage. It also turned out to be an interesting election year, some early outcomes of which were an (almost) hung Parliament under our final (for at least some time) First Past the Post (FPP) election, a referendum decision to move to the Mixed Member Proportional (MMP) form of proportional representation from here on, four parties with members of Parliament (MPs) - the newest one represented by two Maori men, three Maori MPs (one woman and two men) representing "General" rather than Maori electorate seats; the most ever women and Maori MPs, the first Samoan MP, and three new MPs who have been employed in community and continuing education positions.

In recognition of these events, this review of trends and issues in policies, practices and research in community and continuing education in 1993 includes notes on Maori and women as learners and providers. In the first section we report on trends and issues evident in policy developments - from the field, the four political parties now with seats in Parliament and the National Government of 1990-1993. In the second section, trends and issues in the provision of learning opportunities and research are summarised, with particular reference to provisions through local and national community organisations and school community education and to a lesser extent through tertiary institutions and private providers. The review also looks briefly at community and continuing education as they relate to Maori.

A "team" of people, which makes no claim to being fully representative of the "field", have contributed to the development of this review. Dorothy McGray and Alan Addison provided material for the section on the New Zealand Association for Community and Continuing Education's Policy Project and Colin Gunn for the section on trends and issues in the provision of learning opportunities, particularly as experienced by those working through small, local, autonomous community organisations not receiving direct line government funding. Atawhai Bell contributed, through discussion, to trends and issues in relation to Maori and Iwi. Jennie Harré Hindmarsh coordinated the "team", prepared sections on trends and issues in policy and provision and edited the material into the final paper.

In addition, the experiences and views of providers of learning opportunities who receive some direct line Vote:Education funding - schools, some community organisations, universities, polytechnics and colleges of education 
- were canvassed by mail. Sixty-two of the 254 school based community education providers replied to specific questions about 1993 as the first year of the new Ministry of Education guidelines. The NZ Federation of WEAs, three REAPS, Parents Centres and CLANZ responded with information on trends and issues for them in 1993 and on patterns of provision for Maori and women, where available. Three of the six university based continuing education providers, eleven of the 25 polytechnics and one college of education also responded with such information. We are grateful for their contribution to this review and trust that it is of reciprocal use to them. Research reports, papers, newsletters and newspaper cuttings were also sources of information on developments in slices of this diverse "field" to which we refer here as "community and continuing education.

\section{Policy Developments}

The "field" of community and continuing education, sometimes now referred to as "the fourth sector of education" (Benseman, Findsen and Scott, to be published in 1994) was notable both for spheres of activity and inactivity in policy development. On a nationwide level, policy developments in 1993 included the New Zealand Association for Community and Continuing Education Association's policy project, which was funded by the New Zealand National Commission for UNESCO, the four main political parties' statements about the place of community and continuing education in their education policies, and the government's policy programme. Further implementations of government policies developed in the past few years (that is, the 1991 funding cuts, the development of NZQA's role and the new qualifications framework, the new schools community education instructions, Industry skills training and TOPs, summarised in Harré Hindmarsh 1993a) were also biting deeper into patterns of provision of learning opportunities in 1993.

\section{New Zealand Association for Community and Continuing Education Policy Project}

In September 1991 the New Zealand Association for Community and Continuing Education (NZACCE), supported by Community Learning Aotearoa New Zealand (CLANZ), Te Ataarangi, Adult Reading and Learning Assistance (ARLA), the NZ Federation of the Workers' Educational Association (NZWEA), the Aotearoa Community Workers' Association, the National Resource Centre (NRC) and the Rural Educational Activities Programme (REAP), applied to the NZNational Commission for UNESCO for funding under the Participation Programme for 1992/3. The purpose of the funding was

to bring together representative groups to look at the needs, future development, planning, support and resourcing of programmes in adult education and community learning which will benefit marginalised groups in our society (NZACCE, 1991).

In brief, the supporting arguments for the application were stated as follows:

- the limited resources allocated to community education and non formal learning to be targeted to the areas of greatest need;

- the removal of funding from community based groups in the 1991 Budget further disadvantaged marginalised groups; and

- the need for a coherent policy for adult education and community learning is generally acknowledged by people working in that sector of education (NZACCE, 1991).

This project is a response to and a product of frustration with the process and content of governments' policy development. It is a response to both the lack of open and democratic consultation with the "field" in current government policy development processes and to the failures of successive governments to 
implement (or their negation of) the recommendations of the many policy documents developed by government and field based working parties since the 1980s. All these reports (see Tobias 1993a for summary) reiterate the same key points: the need for recognition of the function of community and continuing education in its own right and in relation to other education sectors; the need for redistribution of resources and flexibility in provision to increase equity and more recently to honour Te Tiriti o Waitangi/Treaty of Waitangi; the need for improved funding and accountability systems; and the need for consultation and coordination. The NZACCE project is thus another expression of principles central to community and continuing education in a socio-historical, political and economic context which it experiences as unsupportive of these principles.

\section{Consultative Policy Development Process}

When NZACCE was granted $\$$ U57,000 by UNESCO the Executive set up a working group to co-ordinate the policy development process. An Information Kit (NZACCE, 1993a) and a process of consultation with members, including local and national workshops and meetings, followed. In summary, local branches and members, participating organisations and networks submitted their views on policy questions posed in the Information Kit. These questions requested in put on the following: definitions of "marginalised groups"; how to meet their needs through adult and community education and systems of funding and resources required to make this happen, locally and nationally; and systems of evaluation and accountability required to meet the needs of funders, learners and providers (NZACCE, 1993a).

The fifty responses were collated to form the basis of the development of the first policy draft at a hui held in Wellington in July. This hui was attended by 29 people nominated by their branch, organisation or network - 7 Maori, 20 Pakeha, 1 Tongan and 1 Samoan; 10 men and 19 women. Twenty-three represented urban and 6 rural providers; 20 the North and 9 the South Island.
The draft policy statement was circulated for comment and workshopped at NZACCE's Annual Conference in Christchurch in August. A second draft was developed and further amended into a third which is to be circulated for comment as this paper goes to press.

In preparing for this consultation process NZACCE invited the Minister of Education to write a letter for the Information Kit. In his letter the Minister applauded NZACCE for the project and stated that he saw this as "an ideal opportunity to receive structured input from groups working in the area of adult education and training, especially those based in the community context" to assist the government to put in place his vision of "an education system that is inclusive, diverse and seamless". He provided some questions for consideration regarding views on "desired outcomes" from "community-based adult education and training", "priority areas", the allocation of and criteria for access to public funding, funding sources for research and information brokerage, accountability systems, recognition of the learning achievements of "community-based adult students" and any modifications required of the National Qualifications framework (Smith, 1993).

Not surprisingly, the draft Policy Statement lists as the most important issues and concerns those contained in the reports and recommendations of the 1980s: recognition, funding and accountability, the implementation of equity principles and of Te Tiriti o Waitangi, along with the need for providers to work cooperatively, to network in their local communities to share resources and information and also the need for increased provision of research and professional development (NZACCE, 1993b). In effect it restates the themes of the last decade most of which are still awaiting a positive government response.

Now it is intended that the policy document be used as a basis or reference point for funding submissions, for lobbying Government, MPs, local body politicians, and for responding to Ministry of Education policy projects. It will also be used to 
encourage change and reform within groups, organisations and institutions providing learning opportunities in the "field".

\section{Political Parties' Election Manifesto Statements}

How does this policy statement from the "field" of community and continuing education compare with the election manifesto of the four political parties represented in the Parliament we elected in November 1993? Where do they stand in relation to these continuing themes of recognition, funding and accountability, Te Tiriti o Waitangi and equity, and consultation and coordination?

\section{Alliance}

In the context of its rejection of "market principles" and "aggressive competition" (Alliance 1993a, p. 3) introduced into education in the last decade, the Alliance defined education as "central to democracy and the empowerment of people" (ibid, p. 2). Effective education, the Alliance said, is based on "a partnership between Maori and pakeha in terms of Te Tiriti o Waitangi", "a gender-inclusive curriculum and equal opportunities to learn", full government funding, "including support for community education" and "ongoing consultation and co-operation" (ibid, p. 3). Their education policy listed community education as one of five parts to the education system - along with early childhood, primary, secondary and tertiary education, the latter including vocational education and training.

The Alliance then proceeded to define community education as part of tertiary education and in so doing it stated

that non-institutional, community-based providers of tertiary education should be encouraged, adequately [and equitably]

resourced and monitored as a means of empowering communities (ibid, p. 13)

and that co-ordination and liaison in the field would be ensured locally through the functions of the proposed regional education bureaux. Alliance undertook to base its negotiations for reforms in non formal and community education on the recommendations of the 1989 Learning for Life Report. Specifically it stated that it would increase funding for "acknowledged" community education, restore funding to WEAs so that this was "fair and equitable" in relation to other tertiary providers, take account of developmental work done by WEAs and the need to be able to employ "professional staff", make separate provision for increased funding for adult basic education, and encourage the increased provision of adult basic education through both education institutions and community organisations (ibid, p. 13).

\section{Labour}

The Labour Party developed its "plans for education" through a series of nationwide "education priority setting forums" to which "educational professionals and interest groups" were invited to comment on Labour's draft priorities and to engage in dialogue about problems and concerns (Labour, 1993a, p. 2). The outcome of this process was published in July 1993 as Labour's Plan for Education (Labour, 1993b). Labour stated that its education policy was based on the belief that education is an "investment" for the future, is to "upgrade the level of skill and competency" in the work force, "is the key to equality of opportunity in life, and fundamental to a society in which each and every individual is able to achieve his or her full potential". Equity and fairness in provision was crucial (ibid, p. 5). Labour's education principles were listed as a lifelong learning culture, public education: education as a right not a privilege, quality, Treaty of Waitangi, fairness, equity and access, partnership - between parents, the community and industry, and environmental awareness (ibid, pp. 6-7).

Within this frame, Labour listed as one of its eight "strategic educational priorities" the establishment of "a co-ordinated plan and funding mechanism for open and community learning", stating that it would develop its strategic plan through a 
consultative planning forum process (ibid, pp. 7-8). The goal of "open and community education" was defined as aiming:

to advance the learning culture by increasing adult participation in education and expanding the choices for open learning (ibid, p. 24).

"Open learning" essentially referred to distance learning and it was stated in the section on Maori education that this would be developed with particular attention to Maori needs (p. 26). In the community learning arm to this section it was stated that Labour would develop one coordinating and funding body for "community and adult learning", responsive to community needs and Government guidelines, Labour expected the major priorities to be adult literacy, numeracy, learning assistance, English for speakers of other languages, parenting and job-seeking skills. A Labour Government would develop a suitable and stable funding formula, promote paid educational leave, and begin to restore funding to "community and adult education" in the first budget (ibid, p. 24).

\section{New Zealand First}

The New Zealand First Party also conceptualised education as an investment - "the key investment that New Zealand must make towards economic and social recovery" (New Zealand First, 1993, p. 3), with an emphasis on education as a "value added industry" (p. 1). Furthermore, education was considered to be in the national interest, not merely in the "narrow, private interests of the individual" (ibid, p. 1). New Zealand First did not specifically refer to community and continuing education. However, under its tertiary education and training policy it emphasised the importance of TOP programmes which it considered should be made more accessible.

\section{National Party}

The National Party has been the government since its landslide victory over Labour in the 1990 election but retained only a slender majority in the 1993 election. In its election education policy, subtitled "The Most Highly Skilled Nation in the World", the National Party emphasised education as an investment in the economic and social future of our country, and as "the bridge that links them" (ibid, p. 1). The manifesto stated the Government's role in achieving this goal (taken from its document Path to 2010, 1993) as: "to set clear goals for excellence" and "to resource institutions and the community to help students achieve in an environment that removes barriers and takes account of individual needs" (ibid, p. 1). The rest of the manifesto set out how the National Party intended to achieve these goals, the basis of which is set out in the Ministry of Education's discussion document, Education for the 21st Century (1993). As, at this point, the National Party's manifesto repeats the Government's policy developments it will continue to be discussed in the next section.

\section{Government Policy Developments}

The Minister of Education's priority is to develop a "seamless" education system with an emphasis on education as a means to "Skill New Zealand" (Ministry of Education, 1993b; NZACCE, 1993a; National Party, 1993a). As part of this process the idea of "community", "non formal", "continuing" and/or "adult" education as a "sector" of education is being split up, rearranged, redefined and narrowed in current government policy documents. The "field" as an entity is disappearing from government policy development language. This is evident in changes to the Ministry of Education's policy programme and in its discussion document, Education for the 21st Century.

In 1993 the metamorphosis of the Ministry of Education's 1991-92 Adult Education Policy Project has continued. It was redefined in 1992-93 to the Return Education and Training Policy Project and in 1993 this was transformed into the priority two part of the PCET (Post Compulsory Education and Training) Review Policy Project, specifically reframed as the need to consider "the implications for return education and training of proposals for a 
seamless post compulsory education and training structure" (Ministry of Education 1993a, p. 13). This notion of "seamlessness" entered our education policy "talk" in 1992, especially in the context of the development of the new qualifications framework. The idea is that

it nolonger matters which institution or educational programme students are working in: they will all lead to the same nationally recognised qualifications... Community and private providers will be able to be accredited to offer polytechnic and university programmes, as well as "second chance" opportunities.

Industry Training Organisations will be able to develop training programmes, both on and off the job, that meet their industry's future training needs... The education system must be without seams that can form barriers to participation and life-long learning (Ministry of Education 1993b, p. 20).

As well as stating its policy of seamlessness in the public discussion document Education for the 21st Century (ibid, 1993b), the Government indicated that it would give priority only to (and eventually only fund?) those aspects of community and continuing education provision which contribute to Skill New Zealand (industry based workplace educational and training) and within that goal, "second chance" education - and which contribute to parent education under the Parents as First Teachers program. The aim in Skill New Zealand policies is to build a culture of lifelong learning and workplace training, with continuing education in the workplace being as viable and as important as that taking place in tertiary institutions (ibid, p. 16) in relation to the national qualifications framework. In this context the term "second chance" education is used to refer to that learning where people who have "left formal education without qualifications or who are unemployed and seeking qualifications through an alternative route at another stage of their lives (ibid, p. 18). The alternative route referred to is "community and private providers". The latter are a new category of education provider constructed through NZQA as "private training establishments (PTEs)" - offering programmes funded by Government through the Training Opportunities Programme (TOPs) administered by ETSA (Education and Training Support Agency) (ibid, p. 18). The former ("community") are presumably those community organisations operating outside the PTE and national qualifications framework but who may now apply to be accredited to offer, as part of their provision, programmes which fall within that ambit. As noted in relation to 1992 trends (Harré Hindmarsh, 1993a, p. 192), some community organisation providers are registering as PTEs (e.g., ARLA, Te Ataarangi) as are some school community education providers. The new education environment is designed to introduce competition between tertiary, PTE and community providers (Ministry of Education 1993b, p. 18), consistent with market principles.

As noted above, these policy developments offer more (conditional) national and formal recognition to community and continuing education in that providers outside traditional institutions (polytechnics, universities, colleges of education, secondary schools) can now be legitimated by being accredited to offer unit standards on the qualifications framework. It also offers national and formal recognition to learning in "non formal (maybe now a misnomer) and community education" through the recognition of individual learners' achievements. Under the new policies, individual learners' achievements can be recognised formally and nationally through two mechanisms, both of which tie the learning into the national qualifications framework: either through the community/private training establishments' programmes fitting unit standards registered on the national qualifications framework or through the individual applying for the recognition of their prior non-certificated learning directly in relation to a unit standard on the framework or in relation to a qualification offered by a provider. This qualification is recognised directly in relation to the framework or to NZVCC programmes in universities. 
On the one hand, then, these policy signals open up avenues for the "field" to gain more recognition and legitimacy, and thus the promise of more funding - both key issues in policy documents since at least the 1980s. As Tobias puts it:

many of the ideals accord closely with those which have been espoused by adult educators for many years, and there are indeed many progressive elements contained within the new system. Despite this there are also many conflicting elements which derive from the fact that the new system is driven by a number of contradictory forces (Tobias, 1993b, p. 4).

For example, this recognition, legitimacy and funding is conditional on the provision of learning opportunities defined as "second chance", "return", "workplace" and "parent" education and training. These conditions centralise definitions of priorities and learning needs, tying them to unit standards and the qualifications framework, decreasing local control. And they narrow the spheres of government funded community and continuing education provision. Thus these policy developments are perceived as a mixed bag by those in the field - as a threat to the power of communities locally to define their needs and priorities, and as an opportunity to receive increased (if conditional) recognition and funding, particularly an opportunity for those communities and providers for whom "second chance", "return", "workplace" and parent education and training are already priorities or whose programmes can be reconstructed to fit these categories without too much compromise - at a cost of becoming accredited and fitting NZQA requirements. It also an opportunity in that it extends learning opportunities to some previously excluded (ibid, p. 5), again at some cost.

There is no discussion in these government policy statements of those learning opportunities which learners, providers or communities do not want certificated in relation to the framework, nor those to which they give priority but which do not fit state priorities. This amounts to a redefinition of what is considered legitimate community and continuing education, to be "recognised" and funded by the Government. Recognition is conditional on the programme fitting the Skill New Zealand priorities and the national qualifications framework. However, whilst its impact is evident in all provision (see second section of this paper) this redefinition is not complete and has not been fully enacted. Government funding (reduced in 1991) continues to be allocated to Community Learning Aotearoa New Zealand (CLANZ) and Rural Education Activities Programmes (REAPs) and School Community Education whose briefs include resourcing a broad range of community based and defined learning programmes - along with the Adult Reading and Learning Assistance (ARLA) and Parents Centres, whose programmes explicitly fit the stated Government priorities. There continues to be no direct line funding to Iwi or Maori based programmes through community education. Private providers with this base can apply to deliver TOP programmes, if they can amass the funds required to be accredited.

\section{Provision of Learning Opportunities}

Community and continuing education learning opportunities are provided through local and national community organisations and groups, schools, tertiary institutions and private providers. In this section we review trends and issues in 1993, with particular emphasis on community and school based providers and noting trends for Maori and women as learners and providers.

\section{Community Organisations}

Community based learning is provided and/or resourced through a host of small autonomous local community groups and also through four national community organisations which have continued to receive some direct line Vote:Education funding since the 1991 Budget cuts (Harré Hindmarsh 1993a, pp. 182-86). Often small community groups - characterised by autonomy and local responsiveness - do not consider themselves, first and foremost, as providers of community education but rather as 
providers of health, welfare, justice, cultural or other forms of service. Nevertheless, the bulk of their work is educational and they seek government funding from education, as well as other votes. They provide opportunities to learn skills and knowledge for personal and group development (e.g., self esteem, problem solving, cultural knowledge and skills, family and group processes) and in relation to socially important areas such as unemployment, ethnic and intercultural understanding, social justice, parenting and health. These characteristics, together with the absence of a census and research information, make it very difficult to document and analyse the contributions of such groups to educational development even though it is widely considered that these groups are most significant in the lives of individuals and local communities.

The national community organisations whose primary function is community education development and who continue to receive some direct line Vote:Education funding are the Adult Reading and Learning Assistance Association (ARLA), Community Learning Aotearoa New Zealand (CLANZ) whose function it is to distribute small grants to providers, Parents Centres New Zealand Inc and the Rural Education Activities Programmes (REAPs). The Workers' Education Associations (WEAs) and the Country Women's Coordinating Committee lost their Vote funding in the 1991 Budget. Some national groups, for example Te Ataarangi, have never received ongoing direct line funding (Harré Hindmarsh and Davies, 1993).

In this section we summarise the trends in and issues faced by both local and national community organisations, with a particular eye for what is happening through these organisations for Maori and women as learners and providers. The main themes to emerge in this review are that in 1993 community organisations, local or national, are experiencing severe funding and resource constraints in the face of increased demand for their services and accountability systems, attributed to the effects of the economic downturn and related government policies. They are responding to the implications of the Government's educational and employment policies; they are at various stages in their attempts to become "more bicultural" and/or to promote tino rangatiratanga based Iwi/Maori development; and, in general, they continue mainly to be staffed by women and to involve women as learners.

Increasing demand and decreasing volunteers

Over the last decade government economic and social policies have had a major impact on funding and human resources available, the volume of work and the conditions under which it takes place in local autonomous and national community groups offering community learning opportunities. The increasing pain felt in communities, coupled with the policy of devolving government responsibilities, has contributed to an increased demand for community based programmes. These groups have felt the impact of recent social and economic changes, as represented for example in the rapidly increasing unemployment (the loss of 114,000 jobs nationally between 1985 and 1992) and an increase in crime, where $30 \%$ of the population were identified as victim in 1991-92 and 138 burglaries were reported a day in 1992, up 12\% from 1991 (Reid, 1993, pp. 18-19).

At the same time it has become increasingly difficult to attract volunteers, upon whom such work often relies. More groups have emerged for which volunteers are required. However, women, the mainstay of voluntary services, are more frequently seeking full- and part-time employment to provide or supplement their family income. For example, Parents Centres report that

Parents Centre, along with many voluntary organisations, is finding the going tough as the pressure on women who have traditionally given their time and commitment at the grass roots committee level forces them to limit their participation in the voluntary sector. These women are often now working part-time to supplement family income and limited financial resources and time means little is left over for "altruistic" activities (Parents Centres, 1993). 
Similarly, a REAP reports that

there appear to be fewer and fewer people who are either willing or able to do voluntary work in the community. Many of those committed to working in the community are now employed. (REAP, 1993)

Increasing accountability and decreasing funding

The government's drive for increased accountability and targeting of priority areas, together with the requirement from funders to produce "evidence of need and to specify outcomes", has also resulted in increased pressure on local community groups, national organisations and their workers without a concomitant increase in funding and resources - in fact in the face of decreasing resources (Harré Hindmarsh and Davies 1993, pp. 23-24, 66). In response, community providers are trying to develop their evaluation, accountability, targeting and contracting skills which is boosting the status, professionalism and professional development needs of community education work, but without the technology and staffing resources available in institutions.

This trend to apply economic evaluative models (Ashton, 1992) to community work raises several issues. First, few community organisations have the time or finance to conduct valid need assessments. Second, few organisations have the time or skills to apply sophisticated cost effectiveness and cost utility models. Third, most community organisations view with considerable suspicion models that aim to demonstrate objectively the success of community education work designed to prevent the development of further social and individual problems. Most organisations argue that it is difficult to prove that something did or did not happen because something else was done. Further, even if this was possible, it would be extremely difficult to prove that it was your action (as opposed to other influences and other actions) that made the difference.
The availability of funds for local autonomous groups and most national organisations remains extremely variable, insufficient and unreliable - limiting the range and quality of service provision. The impact of the 1991 Budget cuts is also biting deeper into national organisations. Few groups raise sufficient money to meet their immediate needs. Most face severe funding problems and find it very difficult to plan ahead. Government support for the funding of community based learning is negligible and even when available is distributed through finite Vote (e.g., education, health, welfare), categories which often do not "fit" the more holistic provision of local community groups. A continual source of frustration to many groups is that their services cross governmental administrative structures, thus they are applying for funds to several Ministries or departments (and private funders), each with different systems, criteria and priorities.

Some small local groups find funding is more readily available from Vote:Social Welfare than it is from health or education. Small grants from Vote:Education (see Harré Hindmarsh, 1993a, pp. 182-186; Harré Hindmarsh and Davies, 1993, pp. 16-28) can be applied for through the CLANZ, whose funding was also decreased in 1991- usually for up to $\$ 1500$, but up to $\$ 10,000$ for special projects (see Harré Hindmarsh and Davies 1993, pp. 38-44 for summary of funding distribution 1991-92). In 1992-93 CLANZ distributed its $\$ 200,000$, in amounts ranging from $\$ 125$ to $\$ 9000$, to 159 of the 276 applicants, who had requested a total of $\$ 811,640$. This demonstrates that at least a three-fold increase in funds could be readily used in communities. Some REAPs, polytechnics and universities also reallocate government funded resources to community groups and, as from 1993, school community education providers are required to distribute at least $15 \%$ of their Vote:Education allocation to local community groups. Some of them were already doing so. Even so, demand significantly outweighs the diminishing resource pool. 
The demand is most commonly for programmes where women are the majority of learners. Provisions for women learners have been disproportionally affected by funding cuts. The two national organisations to have direct line Vote:Education funding removed in 1991 served predominantly women learners (WEAs and CWCC) whereas organisations which had fewer funding cuts (ARLA and Parents Centres) cater to a greater proportion of men, relative to other national community organisations (Harré Hindmarsh and Davies, 1993).

Impact of employment and education policies

Changes in funding, accountability and employment contract legislation have all contributed to an increase in tension between community workers and their employers. It appears that the number of paid community education positions has increased in the face of a shortage of volunteers. Most positions are part-time with low pay and insecure tenure and the turnover is high (Gunn, 1993). Most are filled by women (Harré Hindmarsh and Davies, 1993, p. 60); thus women have been particularly affected by this labour force change.

Traditionally, the majority of community groups employing paid workers have done so in a manner that has encouraged a "special" relationship between the employer and employees. Until recently job descriptions and worker contracts were not common. Groups managed their workers in non-hierarchical ways and distinctions between workers and bosses were blurred. Frequently, workers became more "expert" than their bosses, leading them in matters of direction. This relationship often disguised poor supervision, unreasonable hours of service, low wages and poor or non-existent benefits and expense allowances. Recently, with the increase in the numbers of paid workers, the insecurity of their funding, labour legislation and case law there has been an increase in the incidence of worker-boss problems. The demands to attend to these and to negotiate employment agreements has been an additional drain on the limited resources available. For a community organisation whose raison d'etre is "good work" this can be devastating and reduce the productivity of that group (Gunn, 1993).

As noted in the first section of this paper, the development of the national qualifications framework structure is also having an impact on the provision of community based learning. On the positive side the growing acceptance of recognition of prior learning policies (RPL) has allowed and will allow some learning achieved in non formal and informal, non-credit learning settings to be awarded academic credit in relation to a formal programme in an institution or in relation directly to the qualifications framework. This may encourage more community workers to participate in relevant formal qualifications. However, on the negative side, the framework structure itself attempts to package education into boxes which redefine the broad based purposes of community education, as defined by many providers, to narrower goals of skills development, particularly for the paid workplace and parenting.

Another trend related to employment and education policies has been an increase in the availability of formal credentials for those who provide services through community organisations, most of whom are women. For example, a majority of polytechnics now offer such people a Certificate in Community Work (with some recognition of prior learning). At the same time there has been a cost to community organisations. NZQA accredited providers are rapidly moving into positions of strength, and community organisation providers have extreme difficulty in uniting to develop a common stance on issues such as training (for reasons which include autonomy, poor finances and high turnovers). While institutional providers consult locally, no effective national collective of community organisations has developed to balance the strength and influences of these institutional providers of training. Community organisations will continue to provide their own training for their workers but there 
is a danger that this independent and often very practical training will be seen by private and public sector employers as having a second class status.

The devolution of former government responsibilities has been portrayed as the "communitisation" of the public sector. One could also argue that the current trend is for the "privatisation" of the community sector. If and when more money becomes available new and existing private providers will compete with community groups in the provision of services. This has long been evident in early childhood education and care and is expanding into areas till now understood as community education. For example, we now have a rapidly increasing number of private training establishments offering life skills, preemployment and alcohol and drug rehabilitation programmes, and services for people with disabilities - previously offered as a community service.

Despite these trends and issues, community organisations have a commitment to what is often called pro-active or preventative and community development work, which is most resilient. This will continue to be an important part of community education - but will such provisions "secure a place in the sun" (Tobias 1993b, p. 9) of government funding if they do not fit within the qualifications framework and the categories of "second chance" "return", "workplace" or parent education and training? If so, at what cost? If they do not, how will they be resourced? What are the implications of this for community education as we have known it?

Bicultural and Maori development

The themes of bicultural and Maori development - usually with reference to honouring Te Tiriti o Waitangi - have been significant in the 1980s and 1990s and in the development of policy and patterns of provision in community organisations, as well as in the field in general and in national policy papers.
Although no national policies have significantly redistributed resources to Iwi or Maori providers, some Pakeha based organisations committed to this theme have been changing their policies, organisational structures and patterns of provision. For example, ARLA (where Maori represent $14 \%$ of learners) has established Te Whiri Kaupapa Ako, a Maori development committee, appointed a Maori Executive Officer to Te Whiri Kaupapa Ako and has signalled its intention to work towards allocating $50 \%$ of funding to Maori literacy. There has been a significant increase in Maori representation on REAP management committees and of education development programmes by and with Iwi or Maori since 1990. The Parents Centres adopted a commitment to biculturalism in 1991 (Harré Hindmarsh and Davies, 1993, p. 61). In 1992 and 1993 this commitment was developed through national conference and some local branch workshops and visits to local marae (Parents Centres, 1993b). Organisationally, the WEAs are Pakeha, except the Auckland WEA which has structured itself with Iwi and Tauiwi practitioners. Many WEAs have established links with local Maori, some intentionally with mana whenua (under article 2 of Te Tiriti o Waitangi) and others with a local Trust as under article 1 (Peet, 1993). Te Ataarangi continues to operate as a national Maori organisation and many Iwi have continued to develop their own education plans, wananga and other provisions - a trend for Maori to develop and control their own spheres of community and continuing education as well as to continue to push for inclusion, on more appropriate terms, in traditionally Pakeha controlled spheres.

Within these examples are several approaches to bicultural and Maori development, based in liberal or radical constructs of "biculturalism" and/or in tino rangatiratanga (Irwin and Harré Hindmarsh, in progress; Harré Hindmarsh, 1993b). Liberal biculturalisms emphasise Pakeha and Pakeha organisations becoming more "bicultural" and do not significantly redistribute power and control in decision making and resource distribution. 
The result may be more "culturally sensitive" and "tolerant" Pakeha but with Maori still in a less autonomous and lesser position. In contrast, radical biculturalisms essentially focus on changing structures of power. The most common form is based in critical theories and constructs of anti-institutional racism, expressed through "partnerships", creating co-chairs, Maori and Pakeha caucuses and so on. Some have gone further to implement "parallel development". Here the focus is to shift the emphasis from "culture" to that of "rangatiratanga and constitutional sovereignty" (Harré Hindmarsh, 1993b, Irwin and Harré Hindmarsh, in progress).

\section{School Community Education}

The new School Community Education Instructions issued by the Ministry of Education took effect on 1 January 1993. The aims of these instructions were to enable schools offering community education to have greater responsibility for their programmes, to ensure community involvement in programme development through the appointment of a Community Advisory Committee, to require that at least $15 \%$ of the school's Vote funding be available to community groups, to ensure the fair and effective use of funding and to ensure Boards of Trustees were accountable for community education resources. Furthermore, the new instructions required that programmes for which Vote:Education funding was used fall within one of the following categories: adult basic education, training of volunteer community workers, parent education, programmes to meet a defined local community need or personal development (Ministry of Education, 1992; Pedersen, 1992; Harré Hindmarsh, 1993a, pp. 193-195).

To obtain information for this paper all 254 school providers were sent questions regarding trends in the types of programmes they have offered and to which they have allocated resources in the community in 1993, the composition of their Advisory Committee and staffing and their opinion of the new instructions after nine months of operation. As only sixty-two (24\%) of schools replied the information is by no means representative or conclusive. However, the responses give some indication of possible trends and issues which could be followed up with more rigorous research.

Types of programmes

The respondents were asked to indicate the percentage of their courses which fitted the Ministry of Education's categories - both those they provide direct and those they have supported through the $15 \%$ minimum allocation to community groups. Personal development programmes, especially those designed to assist adults to develop work related skills or to move to further education and training, were most commonly offered direct by the schools that replied. Other types of courses in this category were courses to assist beneficiaries and those on low incomes towards self reliance and for specific population groups (e.g., women). Adult basic education (especially ESL, basic Maori language and culture, literacy and numeracy) were the second most common programmes, followed by parent education, volunteer training and programmes to meet a defined community need. Some schools were starting to offer a few self funding or profit making contract courses and NZQA recognised programmes.

Decisions regarding the distribution of at least $15 \%$ of the funding received to community groups were most commonly made by the Community Education Officer in consultation with the Advisory Committee. This funding was allocated to a huge range of groups and programmes offered by local autonomous groups and some national community organisations. "Personal development" programmes were the most common with a fairly even spread of the remainder across adult basic, parent and volunteer education programmes. For example a typical list included some of the following types of groups and programmes: Barnardo's, Parents Centre and Kindergarten (parenting, antenatal and self-confidence courses), Whanau Support, Citizens Advice Bureaux, Parentline, Women's Refuge, Samaritans and 
Victim Support (volunteer training), Te Ataarangi (te reo and literacy), WEA and ARLA (literacy), Pacific Islands Centre (English for new arrivals), marae, WEA and Unwaged and Beneficiaries Trust (personal development). Several schools indicated that in 1993 they had allocated community funds to groups as in previous years; for others this process was new. Two schools stated that they allocated $22-25 \%$ of their funds to community groups.

Key trends in demand and types of programmes offered were noted as shorter courses, increases in courses on Maori language, practical self sufficiency, stress management, vocational skills (especially computers, word processing, crafts for small business) and parent education, increased demand and enrolments, increased professionalism of providers, improved networking with community groups and other providers, and requests from learners for certificates of competence.

Participation of Maori and women

Both school and community group programmes were mainly organised and attended by Pakeha women even if open to mixed groups - with an increasing number of Maori groups obtaining funding for their programmes. No figures are yet available regarding the composition of those attending the 1993 programmes as a whole.

Schools were also asked to indicate the gender and ethnicity of staff responsible for community education and of the Advisory Committee members. Women staff outnumbered men by approximately 2:1 and women tutors outnumbered men by approximately 7:1. Six schools had some Maori staff involved and 22 had at least one Maori tutor (Maori tutors made up between $0 \%$ to $25 \%$ tutors, most frequently $0 \%$ and then about $5 \%$ ). A Pacific Islands staff member was employed in one programme and tutors in two programmes. Nine schools used at least one tutor from other ethnic groups. Pakeha women thus are the most common providers, either as organisers or tutors.
Sixty-five percent of the 55 responses to a question about the composition of Advisory Committees reported a majority of women members. The gender distribution was even in seven $(12 \%)$ of these Committees and men were in a majority on twelve (21\%) Committees. Forty-five percent of the 55 Committees were composed of $100 \%$ Pakeha members. Of the remaining 30 Committees, Pakeha were the majority on all but two, these two having a 50:50 composition of Maori:Pakeha. Thus Pakeha are in the majority on $96 \%$ of Committees. The most frequent distribution where there was a mixed composition was 20\% Maori to $80 \%$ Pakeha. Seven Committees had at least one Pacific Island member and 6 an Asian member. It was not clear from the minimal information requested as to the extent to which particular Committees did or did not reflect the cultural composition of their particular community, although a few schools noted that this was or was not the case.

The new instructions

Fifty-six percent of the 64 replies said that, overall, they had found the new instructions satisfactory and $7 \%$ that they were very satisfactory. Fifteen percent considered them unsatisfactory and one school, very unsatisfactory. Three schools indicated that there were both positives and negatives and three were not aware of the new instructions. Points of dissatisfaction included a strong sense that the Ministry of Education's programme type categories were "too restrictive" or "narrow", "needed to be clearer or more flexible" and "were cramping diversity" and that it is impossible to separate programmes into each type - some programmes are used for leisure, personal development and employment skills at the same time. Other dissatisfactions were the increased demand on the organiser's time and the services of the school required to co-ordinate with community groups without extra resources, the lack of power of the Advisory Committee relative to the Board of Trustees, and the pressure to make some courses self funding when they were important points of social contact for the elderly and isolated people. Points of satisfaction were commonly 
expressed as increased involvement and co-ordination with community groups and other local providers, the support and resource of the Advisory Committee and the removal of the minimum class size rule.

Key issues faced by school community education providers in 1993 included the increased demand for programmes which exceeds funds available and tension between the Advisory Committee and Board of Trustees in some schools where the latter placed priority on financial interests above community education principles, with the Board having the power to act over and above the Advisory Committee. Other issues included ongoing equity matters, the prevention of school students attending programmes, lack of a "mainstreaming" policy, uncertainty about the future impact of the new qualifications framework on provisions, and dissatisfaction with the Ministry's data collection and analysis systems. Overall, it was felt that whilst the new instructions appeared to encourage more "localism", in fact increased "centralisation" of control was experienced - a similar theme to that emerging from community organisations.

\section{Tertiary Institutions}

In general, polytechnics, universities and colleges of education have not made any major changes to their provisions of community and continuing education or patterns of staffing in 1993. Detailed data on course types, ethnic and gender participation rates and staffing for 1993 are not yet available and when available are increasingly submerged within institution wide figures and other ways of categorising data. There is much room for research to tease out continuing and community education data. However, from comments provided by institutional providers the following trends and issues can be gleaned.
Maori and women as providers and learners

Whilst there often appear to be few courses specifically for any one group, most institution based providers are attempting to increase Maori participation and resource allocation to Maori (most typically in a "liberal bicultural development" mode, as defined above) and to ensure the continuation of women's participation whilst increasing the cultural diversity of women as providers and learners. Institutions are attempting to increase Maori access to, if not control of, more resources by employing or planning how to employ more Maori staff with a Maori development and/or bicultural development brief (see Harré Hindmarsh, 1993b and Irwin \& Harré Hindmarsh, in progress, for discussions of the difference). Other means to this end include expanding Maori Studies and offering courses that are by nature for Maori, implementing bicultural development programmes for Pakeha/Tauiwi staff, and in a few cases developing direct cooperation, consultation or partnership links with tangata whenua/Iwi, often through marae based programmes.

Figures and comments readily available indicate that women, especially Pakeha women, continue to dominate as participants, organisers and tutors - slightly less so in university continuing education. In 1993 many institutions offered special courses for women in recognition of Suffrage Year. For example a "Duck Pluckers Day Out" attended by 186 women at Southland Polytechnic, programmes for women staff on menopause and breast self-examination, and the University of Auckland Centre for Continuing Education's "Suffrage Centenary Programme". New Certificates in Women's Studies are also being offered or developed by some university-polytechnic partnerships through Uni-Tech frameworks, women's studies and continuing education departments.

Key trends and issues

Trends and issues for community and continuing education provision through tertiary institutions continue in a similar vein 
to those evident since the passing of the 1990 Education Amendment Act (Harré Hindmarsh, 1993a, pp. 186-88). In universities the trend seems to be to conduct reviews and towards more pressure for programmes and Centres of Continuing Education to operate on a full cost recovery basis. For example, the Centre at Auckland is now $84 \%$ self supporting, having been set on this track in the 1980s. There has also been some growth in return to education type programmes, with some emphasis on those for under-represented groups, elder hostel and college for seniors, and graduate/professional development programmes. The 1992-93 review at Victoria University of Wellington and the recent review at Canterbury signalled the intention to require more cost recovery. Auckland and Otago are planning to review their provisions in 1994. More Maori, especially women, are reentering formal education through tertiary institutions (Davies and Nicholls, 1993, pp. 75, 84, 88) which challenges return to learning programmes to better meet their needs. Colleges of education are developing more outreach teacher training programmes, especially to Maori, and programmes for Boards of Trustees.

For community and continuing education in several polytechnics the issue has been survival, as indicated from the following comments from two polytechnics.

Our provision of programmes and courses is largely determined, these days, by their financial viability. We are less able to support uneconomic courses by more profitable ones because fewer and fewer enter the latter category.

[E]nsuring the survival of a community education provision in a climate that is increasingly being driven by full time technological training [is an issue].

As in the field in general, there has been a mixed response to education policy developments. Some concern is expressed in institutions that government funding may become directly tagged to programmes "on the qualifications framework", which would not recognise with funding the significant contribution of non- formal courses to "hooking" people backinto further learning and to social and cultural contributions. Most of these cannot operate on a self funding basis.

\section{Private Providers}

As with the myriad of local autonomous groups, we have no census or research data which documents and analyses the range of private providers of community and continuing education, which are increasing in the policy context of the 1990s. Some of these private providers were, until very recently, government funded community providers but with the new education language and systems are now recategorised as government funded "private training establishments" - for example the shift from ACCESS and MACCESS to TOP private training establishments. Others operate in the "private" sector in that they are funded directly by the clients and/or industry. Whatever their source of funding, most private providers are assuming a new significance, increased recognition and are being drawn into the central government's national qualification system. Through accreditation by NZQA, they are offering programmes which fit the unit standards being developed on the new qualifications framework and through the new Industry Training Organisations. Given that data from polytechnic ACCESS programmes from the past indicates that Maori are more likely than other students to be in these courses (Davies \& Nicholls, 1993, p. 88), it can be suggested that Maori are also more likely to be participating in and providing PTE TOP courses. Research is needed on this trend and on the opportunities and issues it presents in relation to Maori/Iwi development.

\section{Who Is Deciding? Who Is Benefiting?}

From this summary of trends and issues in the provision of community and continuing education in 1993 it can be concluded that, in general, whilst some ground has been made, Maori still do not benefit or decide on priorities, either in proportion to their 
numbers or as full "Treaty partners". However, there are notable pockets of development and provision where policies of honouring Te Tiriti o Waitangi, of bicultural and/or tino rangatiratanga based developments are beginning to take effect. These approaches to development warrant further study (Harré Hindmarsh, 1993b; Irwin \& Harré Hindmarsh, in progress). Maori or Iwi based initiatives continue to struggle with little or no direct or indirect Vote:Education funding.

Women, especially Pakeha women, predominate in this field - but more often than not on a shoestring existence. Women are particularly being affected by the new employment and education contexts. These offer both promises of more recognition and threats of increased central and/or funder control.

Trends and issues in policy and provision continue to be those of recognition and legitimation (on whose terms?), funding and accountability, Te Tiriti o Waitangi and equity, and co-ordination - to which are added the tensions and contradictions between local and central state control and between economic, social and cultural priorities.

\section{References}

Alliance Party. Alliance Education Policy, Wellington, June 1993a.

Alliance Party. Alliance Women's Policy, Wellington, 1993b.

Ashton, T. The Economics of Health Promotion, Auckland: University of Auckland, 1992.

Benseman, J., Findsen, B. and Scott, M. The Fourth Sector: Adult and Community Education in Aotearoa/New Zealand, Palmerston North: Dunmore Press, to be published in 1994.

Davies, L. and Nicholl, K. Te Maori i roto i Nga Mahi Whakaakoranga, Maori in Education: A Statistical Profile of the Position of Maori Across the New Zealand Education System, Wellington: Ministry of Education, 1993.

Gunn, C. "Community based learning: some present trends and future possibilities", in New Zealand Journal of Adult Learning, 21, 2, 1993, in press.
Harré Hindmarsh, J. “Community and continuing education in 1992: trends and issues", in Manson, H. (ed), New Zealand Annual Review of Education Te Arotake o Tau o Te Ao o te Matauranga i Aotearoa, 2:1992, Wellington: Faculty of Education, Victoria University of Wellington, 1993a.

Harré Hindmarsh, J. "Facing the Limitations of Biculturalisms and Antiracisms: Work in Progress", Paper presented at Confronting Racisms Conference, Sydney and the World Indigenous Peoples' Education Conference, Wollongong, 1993b.

Harré Hindmarsh, J. and Davies, L. Vote Education Funding for Adult Education: Who Benefits? Part One: Community Organisations, Wellington: Ministry of Education, 1993.

Irwin, K. and Harré Hindmarsh, J. Partnerships in Practice: Case Studies of Maori and Bicultural Development, in progress.

Labour Party. Labour Education Priority Setting Forum - Workbook, Wellington, 1993a.

Labour Party. Education - Our Children, Our Future: Labour's Plan for Education, Wellington, 1993b.

Meade, A. "The Labour Market and the Universities", Paper presented at NZCER and AUSNZ Seminar, Wellington, 14 October 1993.

Ministry of Education. "School Community Education Instructions", Wellington, 1992.

Ministry of Education. Policy Work Programme, 1 July 1993 to 30 June 1994, Wellington: Ministry of Education, 1993a.

Ministry of Education. Education for the 21st Century: A Discussion Document; Wellington: Ministry of Education, 1993b.

National Party. Policy'93 - The Most Highly Skilled Nation in the World: The National Party's Education Policy, Wellington: National Party,1993.

National Party. Path 2010, Wellington: National Party, 1993. NZACCE. "Application to the NZ National Commission for UNESCO Participating Programme", Auckland: NZACCE, 1991.

NZACCE. Information Kit Policy Project, Auckland: NZACCE, 1993a.

NZACCE. Draft Policy on Adult and Community Education (3rd), Auckland: NZACCE, 1993b.

New Zealand First Party. Tertiary Education and Training, Wellington: New Zealand First Party, 1993. 
Parents Centres, personal communication, 1993.

Parents Centres, Annual Report, Wellington, 1993.

Pedersen, E. "School Community Education Programme Information" in Lifelong Learning in Aotearoa, 3, December, 1992, pp. 24-25.

Peet, K. President, Federation of WESA in Aotearoa New Zealand, personal communication, 1993.

REAP, (Ruapeheu), personal communication, 1993.

Reid, B. "The Pain Factor", in Time, 15 March, No. 11, 1993.

Smith, L. "Ministers Letter and Appendix", in NZACCE, 1993a.

Tobias, R. "Summaries of Key Documents in the 1980s", in NZACCE, 1993a.

Tobias, R. "The Politics of Meeting Learner Needs", Draft of Paper presented at NZACCE Conference, Christchurch, 1993b.

\section{The authors}

Jennie Harré Hindmarsh, a Pakeha, is employed as Senior Lecturer in Continuing Education at Victoria University of Wellington. Her current research activities include studies of biculturalisms and antiracisms, adults' learning pathways, the recognition of prior learning, and "developmental evaluations" of community education programmes. Her recent publications include a paper in this Annual Review 1992, a study with Lisa Davies of Vote:Education funding to community organisations (Harré Hindmarsh \& Davies, 1993) and conference papers on "Facing the Limitations of Biculturalisms and Antiracisms".

Atawhai Bell of Tuhoe is employed as Maori Community Education Officer at Victoria University of Wellington. Her current activities include the development of Maori studies in continuing education and marae based programmes, in partnership with tangata whenua.

Alan Addison is employed as a Director of School Community Education in Auckland. He has been Chairperson of Community Learning Aotearoa New Zealand (1991-1993) and is Co-President elect for the New Zealand Association for Community and Continuing Education.

Colin Gunn is a Community Education Tutor at Nelson Polytechnic. He works with many autonomous community organisations in the Nelson region and is also a trustee for the National Resource Centre for Community and Adult Learning.
Dorothy McGray has been Co-President of the New Zealand Association for Community and Continuing Education from 1989 to 1993 . She is also employed as the Co-ordinator of the West Auckland Workers' Education Association. She has published several articles in recent editions of Lifelong Learning in Aotearoa and Akina. 